\title{
An overview of the applications for early warning and mapping of the flood events in New Brunswick
}

\author{
D. Mioc ${ }^{1}$, E. McGillivray ${ }^{2}$, F. Anton ${ }^{1}$, M. Mezouaghi ${ }^{2}$, \\ L. Mofford ${ }^{2} \&$ P. Tang ${ }^{3}$ \\ ${ }^{I}$ National Space Institute, Technical University of Denmark, Denmark \\ ${ }^{2}$ New Brunswick Emergency Measures Organization, Canada \\ ${ }^{3}$ New Brunswick Department of Environment, Canada
}

\begin{abstract}
This paper gives an overview of the on-line flood warning implementation in the province of New Brunswick, Canada. The on-line flood warning applications are available via the "River Watch" website provided by the New Brunswick Department of Environment. Advanced GIS technology combined with hydrological modelling, provide a mapping and visualization tool that can be used by emergency managers and the general public to predict possible flood zones. The applications developed for "River Watch" support the processing of large amounts of digital terrain and hydrological data, which are then, quantified and displayed on digital maps allowing decision makers and the general population to comprehend and visualize the possible area and impact of the flooding. The WebGIS applications that are available from the "River Watch" web site provide snow reports and maps, flood warnings and interactive maps. The searchable historical database containing reports about the impact of past floods and estimated damages provides a valuable insight into the past of the province of New Brunswick and the motivation for development of the system for flood prediction and management.
\end{abstract}

Keywords: flood maps, flood prediction, flood management.

\section{Introduction}

In the province of New Brunswick (Canada), river valleys and flood plains can pose a risk because of ice jams, harsh weather and floods of annual spring thaw. 
Another danger comes from hurricanes, tropical storms, erosion, or other harsh seasonal weather events, which may cause tidal and ice surges in coastal areas (see Figure 1). All of these can cause a threat of flooding with material damage to people and even the loss of human lives [1].

In Canada, the province of New Brunswick was the first province to join the Flood Damage Reduction Program signing General, Mapping and Studies Agreements in March 1976 [2]. The first outcome of this agreement was mapping of the flood plain, where one in a 100-year flood was used to delineate and designate flood plains in 13 areas [2].

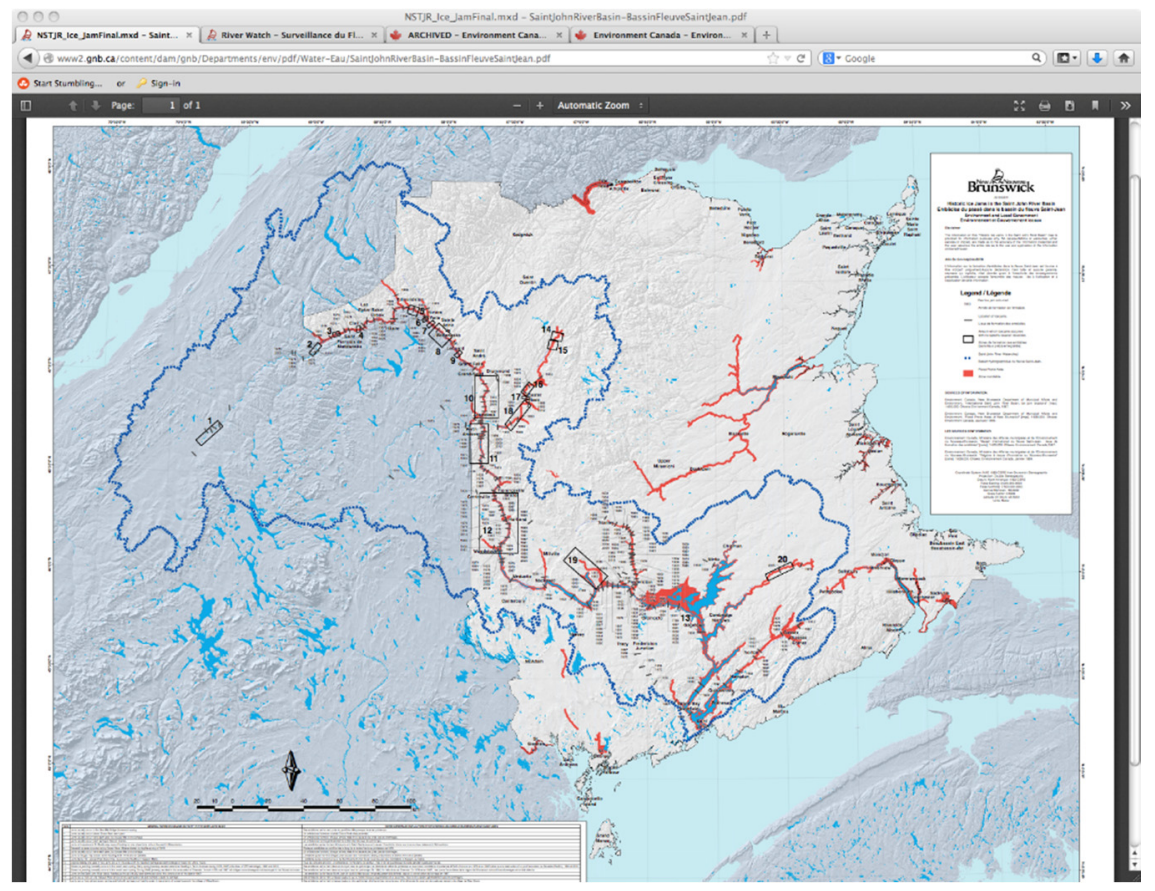

Figure 1: Historic ice jams in the Stain John river basin (from: http://www2.gnb.ca/content/dam/gnb/Departments/env/pdf/WaterEau/SaintJohnRiverBasin-BassinFleuveSaintJean.pdf).

Within this program, a sub-agreement on structural controls centered on building sea dykes in the Petitcodiac area was made. This separate agreement for flood control (where each party assumed one third of the costs in the Marsh Creek area) was negotiated with the federal and provincial governments and the city of Saint John. The flood management related works provided by this program included channel improvements, improvements to outlet control structures, the construction of a reservoir and the reconstruction of a bridge [2].

Additional studies agreement funded ice research on the Restigouche River and the international section of the Saint John River [2]. 


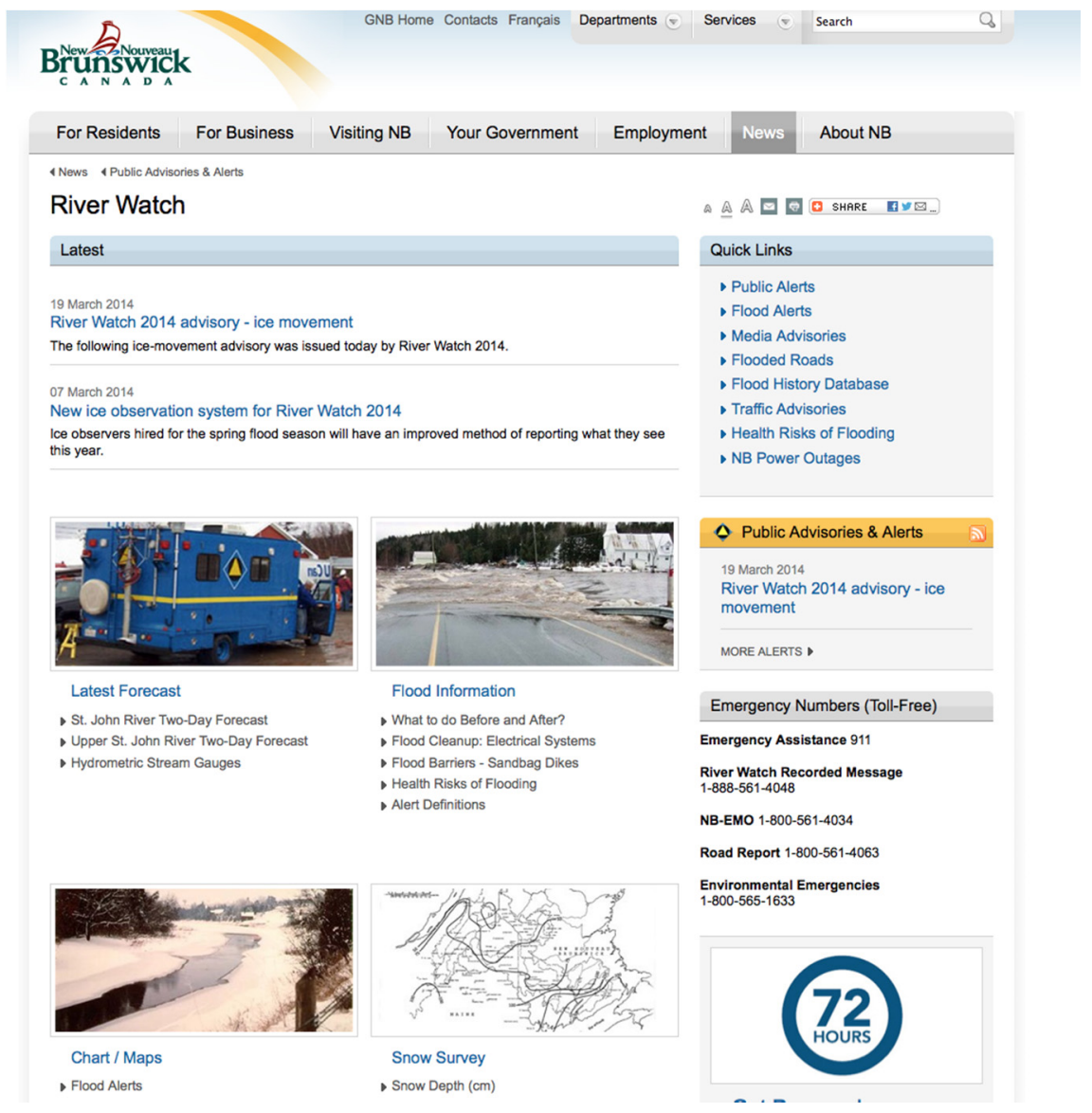

Figure 2: River watch web site (from: http:/www2.gnb.ca/content /gnb/en/news/public_alerts/river_watch.html).

This sub-agreement on flood forecasting followed by the Geoconnections funded project on flood prediction and mapping helped the province of New Brunswick to establish a flood forecasting centre for the Saint John River, including the required technology development and transfer. The River Forecast Centre (RFC), located in Fredericton, forecasts river levels and produces interactive near real time flood maps along the Saint John River and its main tributaries below Fredericton where the major flood damages are experienced in the province (see Figures 1 and 2). The RFC provides this service on everyday basis during the spring freshet as well as during flood events following heavy rainfall [2].

The basic flood facts [3] are presented here:

- A heavy rainfall can result in flooding, particularly when the ground is still frozen or already saturated from previous storms, for example the 
flooding that usually happen in spring time [3], sometimes even with the ice jams (see Figure 3).

- Flash flooding - in which warning time is extremely limited - can be caused by hurricanes, violent storms or dams breaking, that became more frequent in recent years [3] what is attributed to the climate changes.

- Many Canadian rivers experience frequent flooding. The potential for flood damage is very high if residential or commercial development is allowed on low-lying, flood-prone lands [3]. The regulation for building permits should exclude construction on the flood plain.

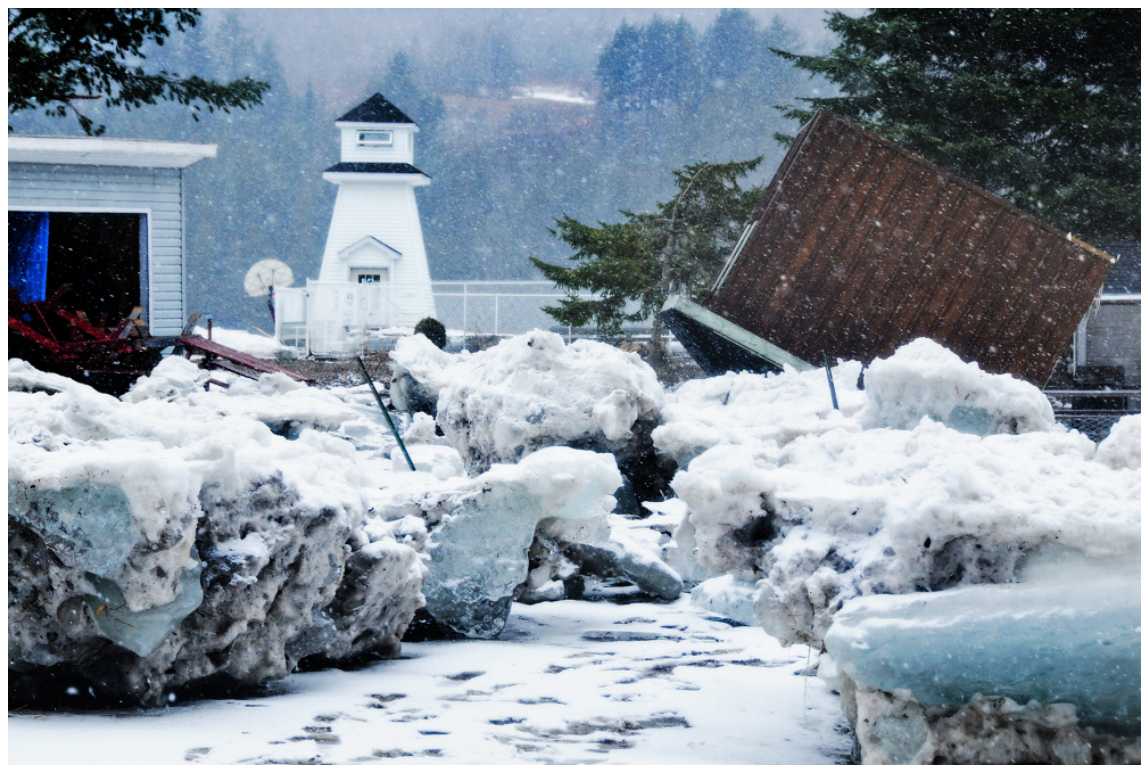

Figure 3: Ice Jam Flooding: an ice jam in the St. John River caused major flooding, impacting homes, businesses and public infrastructure in the Perth-Andover area (from: http://www2.gnb.ca /content /gnb/en/multimedia/mrenderer .2012.03.2012-03-25_1.jpg.html).

\section{The on-line available applications for flood forecasting and management in "River Watch"}

There are several interactive applications available to the users accessing "River Watch" web site. The general web site (shown on Figure 2) provides the links to the individual applications about snow (see Figure 4), ice or flood status and warnings. There is a link to the information about the conditions on the roads provided by New Brunswick Department of Transport shown on Figure 5. The additional information about the road accessibility or closure is given in tabular 


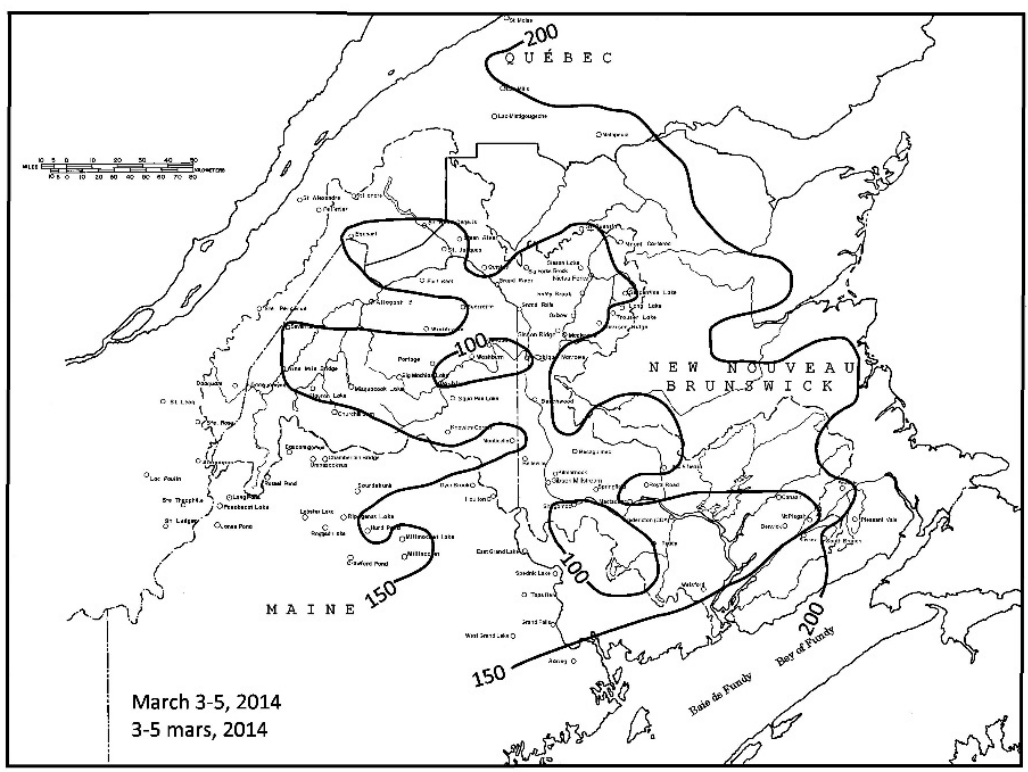

Figure 4: The Web map application showing the snow depth for the whole province of New Brunswick (from: http://www2.gnb.ca/content /gnb/en/news/public_alerts/river_watch/survey_depth_cm.html).

form directly at the web site [4]. The interactive maps that show flooded areas in near real time are updated on a daily basis (see Figure 6). In Figure 7, a more detailed view of the Saint John River watershed is shown, and Figure 8 shows a detailed daily flood map for the City of Fredericton, with interactive graphs providing the readings for water gauges along the hydrographic network.

While the flood maps are produced and updated on a daily basis [5], hydrological modelling [6] provides the possibility for forecasts for the next two days of the water levels along the Saint John River (shown on the table in Figure 9).

A service for reports and warnings about ice jams is developed as well (see Figures 10 and 11). The valuable knowledge about the past floods and their impacts to the people living in the province of New Brunswick is compiled and available via the utilization of the historical database. The database provides search utilities and reports to the users (see Figures 12 and 13). 


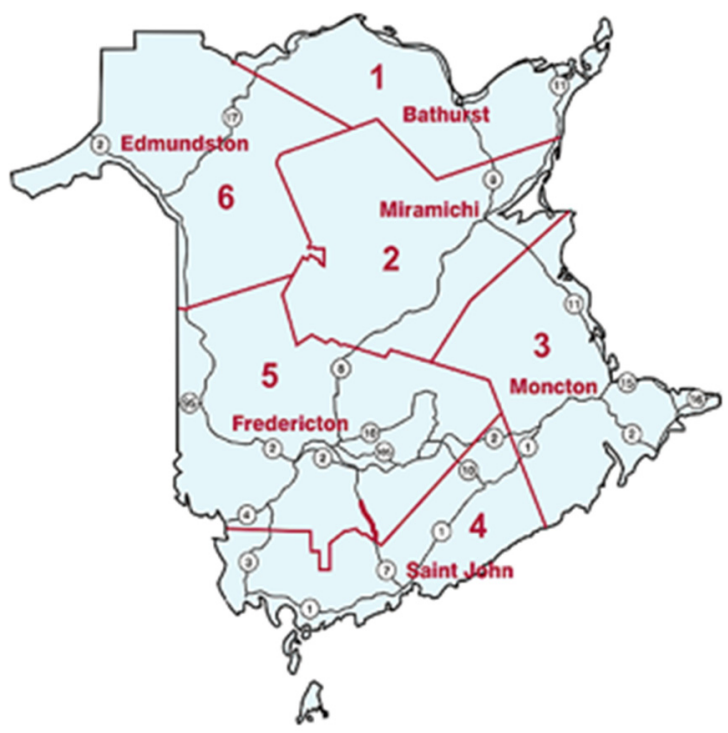

Figure 5: The roads condition in New Brunswick (from: http://www1.gnb.ca/0113/en/traffic_advisories/flooding-e.asp).

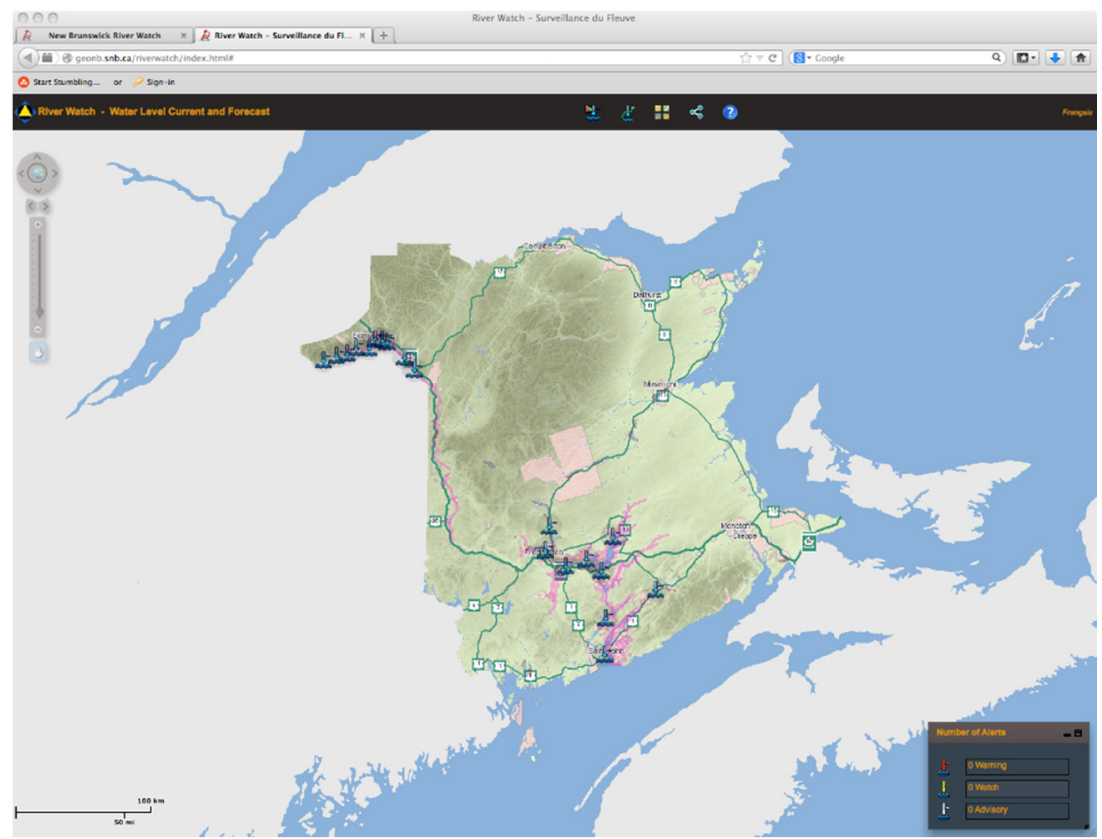

Figure 6: Interactive flood warning map for the province of New Brunswick [4]. 


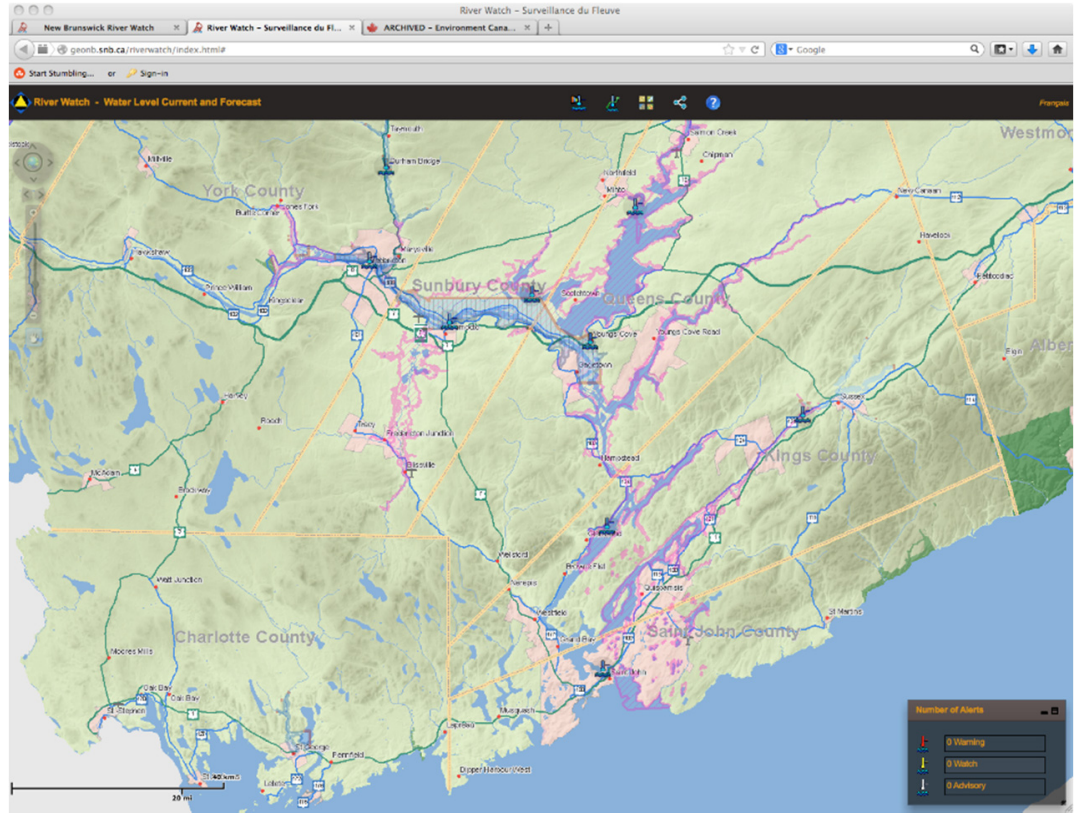

Figure 7: Interactive flood warning map for the province of New Brunswick, "zoom-in" for Saint John River watershed [4].

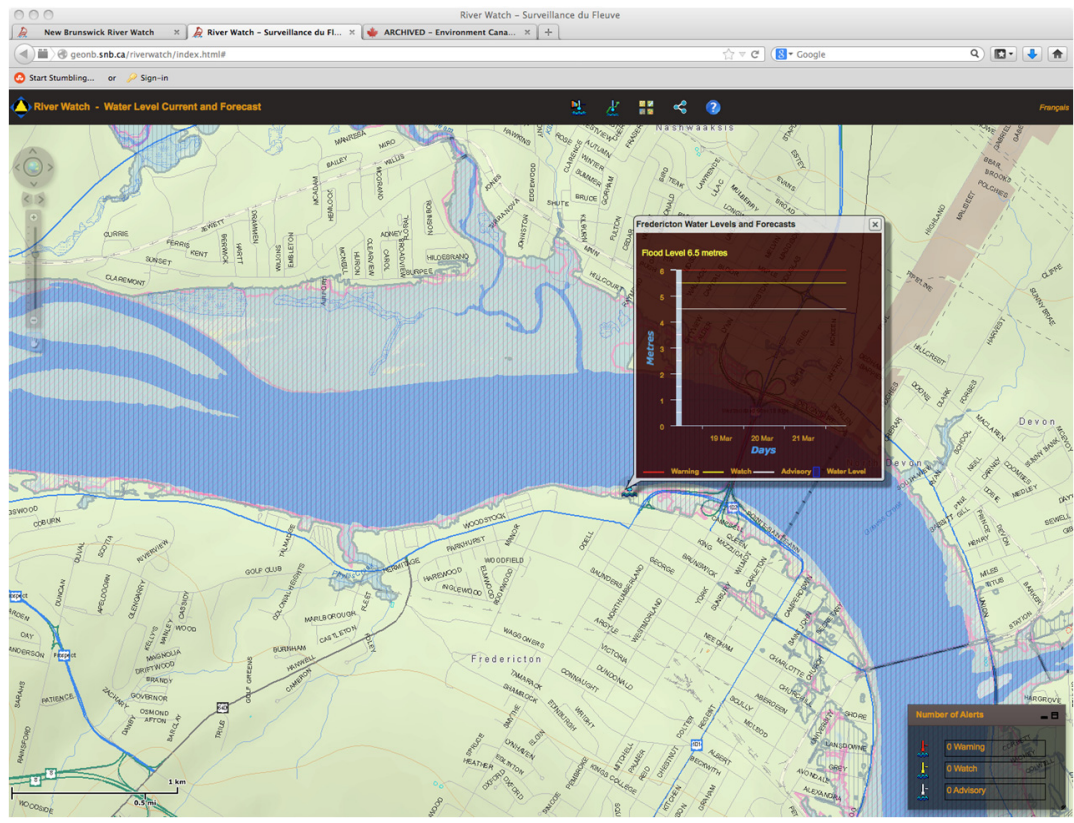

Figure 8: Interactive flood warning map for the province of New Brunswick, "zoom-in" for the City of Fredericton [4]. 


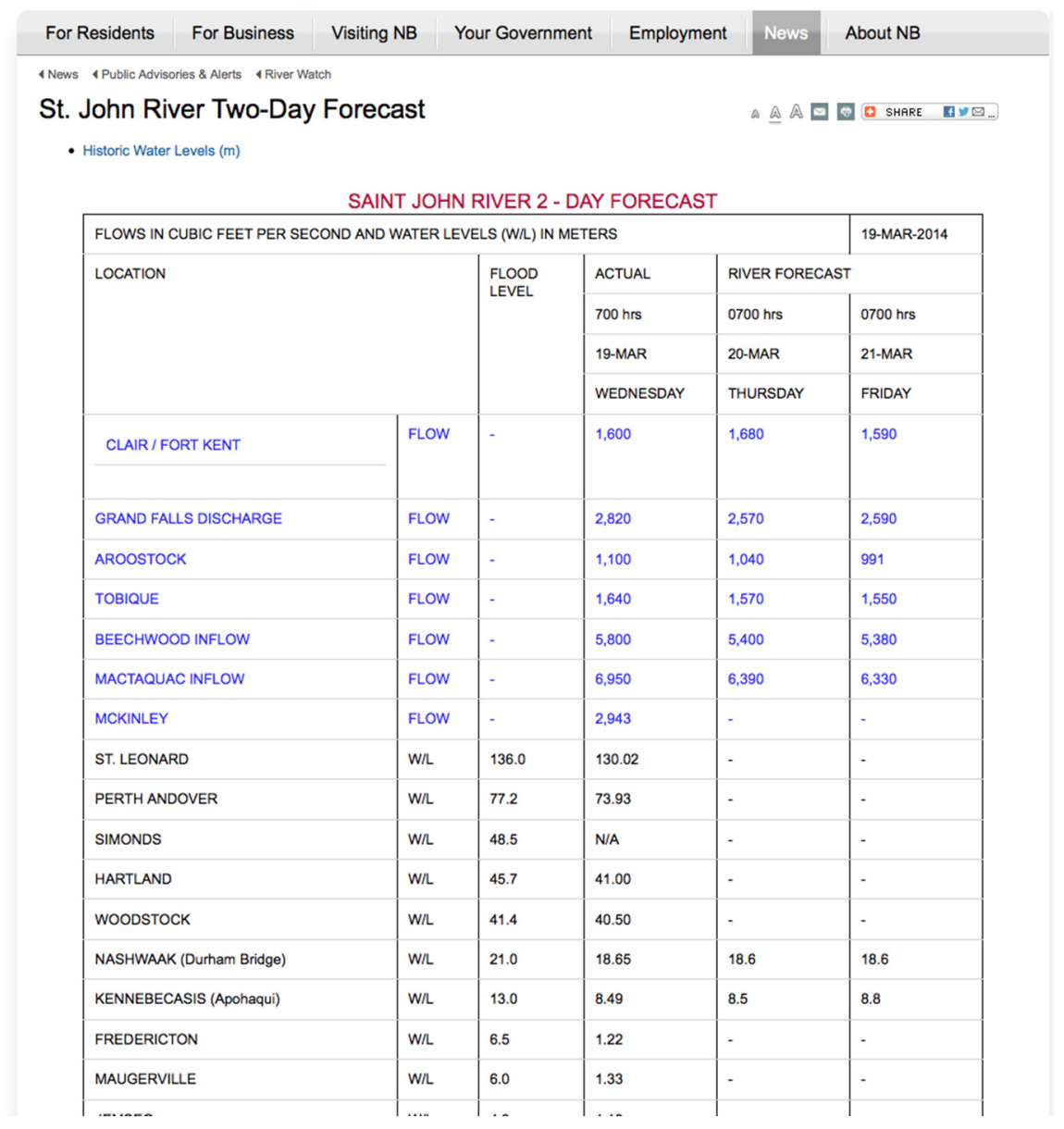

Figure 9: Two days forecast for Saint John River (from: http://www2.gnb.ca /content/gnb/en/news/public_alerts/river_watch/st_john_river_two -dayforecast.html). 


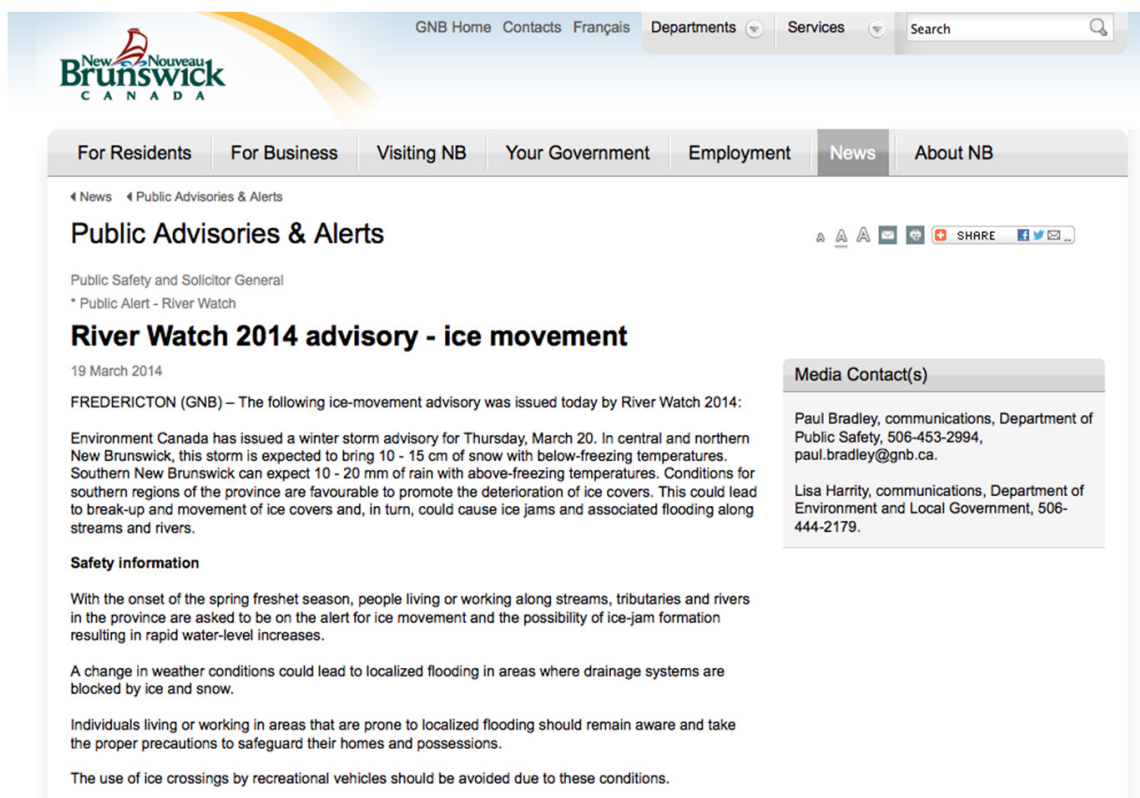

Figure 10: Ice movement warnings (from: http:/www2.gnb.ca/content /gnb/en/news/public_alerts/public_alert.2014.03.0266.html).

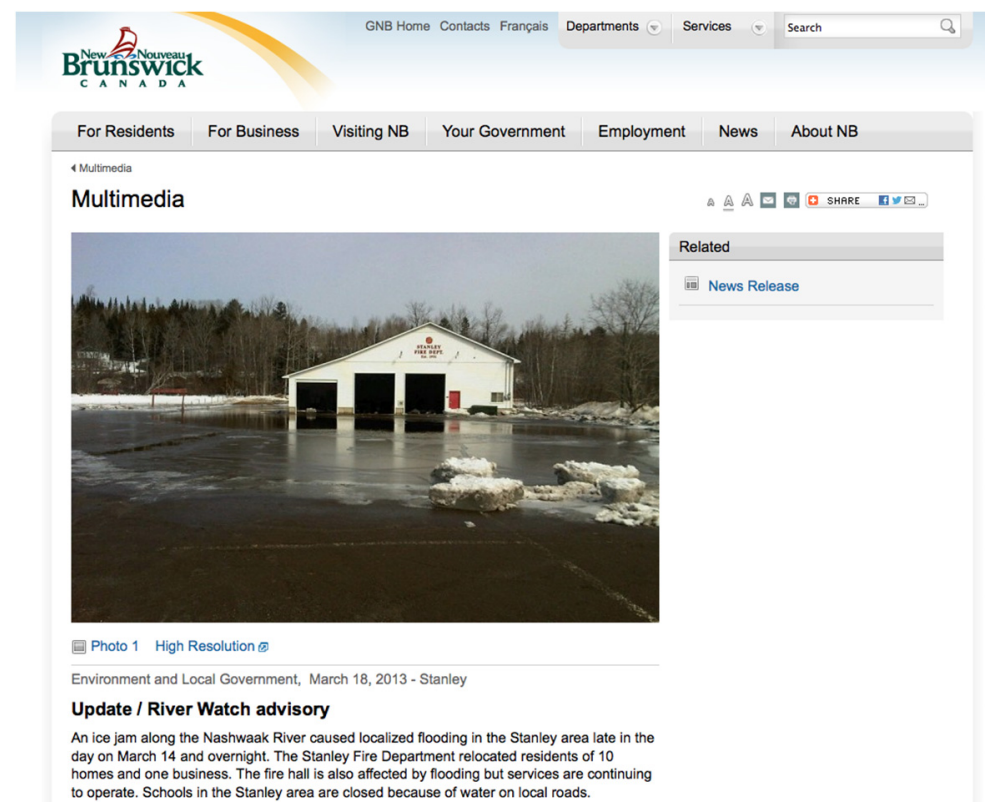

Figure 11: Ice jam in Stanley, NB (from: http:/www2.gnb.ca/content /gnb/en/multimedia/mmrenderer.2013.03.2013-18-03_3.jpg.html). 


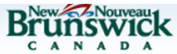

\section{Environment and Local Government}

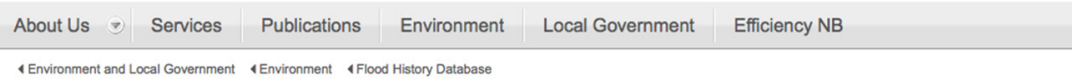

Flood Details - 2008-04-23 - 2008-05-02

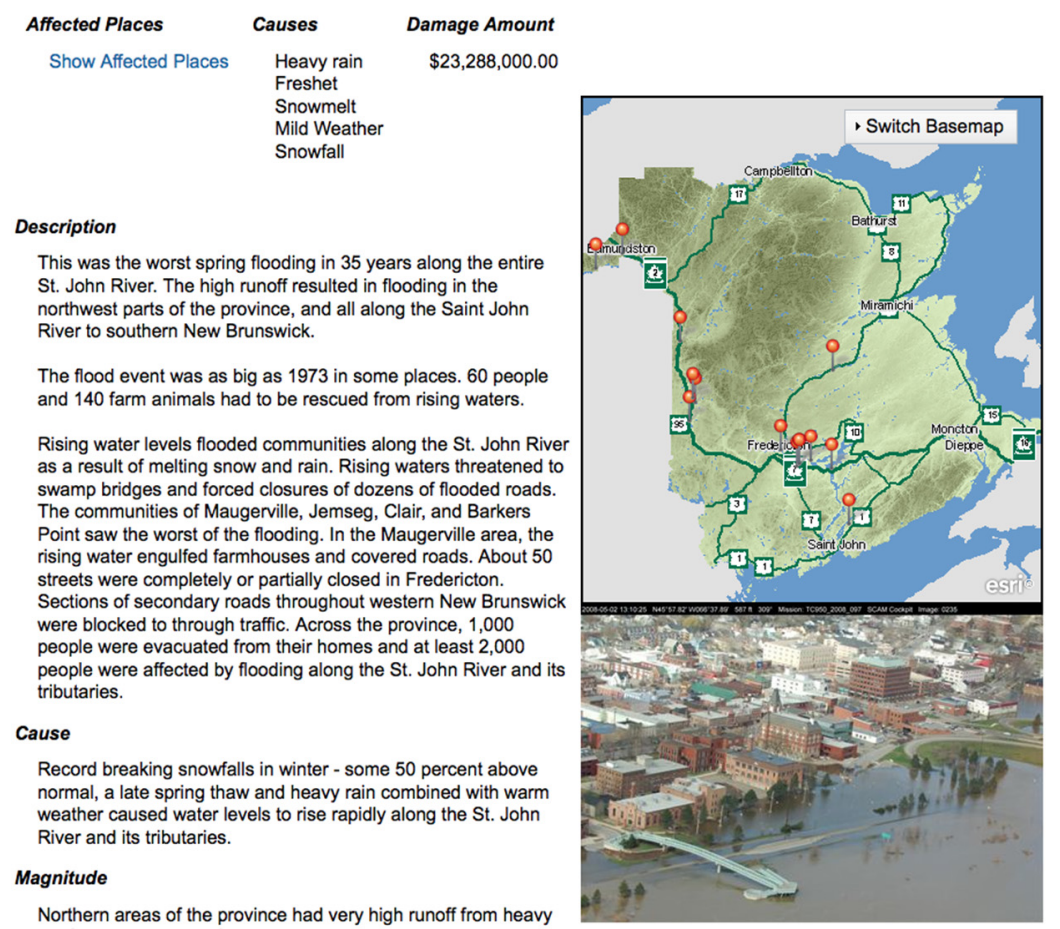

Figure 12: Detailed report about flooding in 2008 (from: http://www.elgegl .gnb.ca/0001/en/Flood/Details/304). 


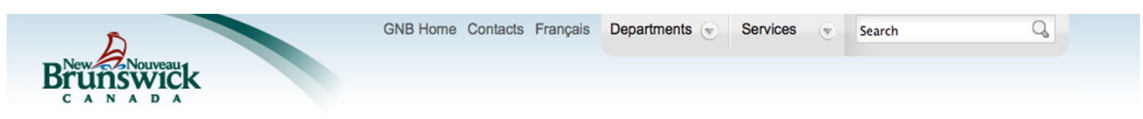

\section{Environment and Local Government}

\begin{tabular}{|c|c|c|c|c|}
\hline About Us $\rightarrow$ Services & Publications & Environment & Local Government & Efficiency NB \\
\hline IEnvironment and Local Government & AEnvironment $4 \mathrm{Flo}$ & d History Database & & \\
\hline \multicolumn{5}{|l|}{ Search } \\
\hline Location Name & fredericton & & Minimum Damages & \\
\hline Occurred Before & eg: 2012-12-3 & & Occurred After & eg: 2012-12-31 \\
\hline Text Search & & & Flood Cause & + \\
\hline
\end{tabular}

Results (88)

\begin{tabular}{|c|c|c|c|c|c|}
\hline 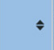 & $\begin{array}{l}\text { Start } \\
\text { Date }\end{array}$ & $\begin{array}{l}\text { End } \\
\text { Date }\end{array}$ & $\begin{array}{l}\text { Damage } \\
\text { Amount }\end{array}$ & Photos $\uparrow$ & Description \\
\hline Details & $1759-11-03$ & $1759-11-04$ & & 0 & $\begin{array}{l}\text { Fundy Coast: At Saint John, a "Saxby" type combination of windstorm and tides caused } \\
\text { extensive damage. }\end{array}$ \\
\hline Details & 1768-01-01 & $1768-12-31$ & & 0 & A store at Fredericton was swept away by ice. \\
\hline Details & $1798-10-01$ & $1798-10-03$ & & 0 & $\begin{array}{l}\text { At Fredericton and Maddeskesway (Keswick) and along the Nashwaak and Oromocto rivers, } \\
\text { many families lost stock and provisions. }\end{array}$ \\
\hline Details & 1831-04-11 & 1831-04-11 & & 0 & There is some confusion in the newspaper reports regarding the year. \\
\hline Details & $1846-03-20$ & 1846-04-05 & & 0 & Saint John River Basin: A bridge was destroyed on the Aroostook River. \\
\hline Details & $1851-10-31$ & $1851-11-04$ & & 0 & Saint John River Basin: A rapid rise of water occurred at Grand Falls on October 31. \\
\hline Details & $1854-05-01$ & 1854-05-31 & & 0 & No reports were available from 1854 describing this flood or the damages caused. \\
\hline Details & $1857-04-01$ & 1857-04-01 & & 0 & Fredericton Area: Piling up of drifting ice caused flood damage in and around Fredericton. \\
\hline Details & $1887-04-25$ & $1887-05-14$ & $\$ 500,000.00$ & 4 & Saint John River Basin: On April 26, the ice began running above Andover. \\
\hline
\end{tabular}

Figure 13: Historical database of floods in NB (from: http://www.elgegl.gnb .ca/0001/en/Flood/Search?LocationName=fredericton).

\section{Conclusions}

An overview of the flood prediction and mapping applications available on-line from the "River Watch" web site has been presented. The online applications allow access to flood forecast data and mapping services for ice jams, roads accessibility or closure and near real time flood plain delineation. The historical database provides the utilities for search and access to data about past flood events and damages that were caused. The flood prediction and mapping applications and other services provided by "River Watch" are accessible to the decision makers and general public in order to assist them to comprehend the impacts and potential damages of the flooding.

\section{Acknowledgements}

This project was financially supported, in part, by the N.B. Emergency Measures Organization and by the Canadian Department of Natural Resources Geoconnections program as well as by University of New Brunswick and New Brunswick Innovation Foundation (NBIF). The IT Division of the City of Fredericton and Geological Survey of New Brunswick provided datasets available for this project. The New Brunswick Department of Environment has provided 
data and expertise related to hydrological modelling, and the NB Emergency Measures Organization helped with their expertise and additional funding for this project.

\section{References}

[1] Hazards in New Brunswick, http://www.getprepared.gc.ca/cnt/hzd/rgnl/nbeng.aspx, accessed on-line, March 2014.

[2] Environment Canada, Flood damage reduction program, https:/www.ec.gc.ca/eau-water/default.asp?lang=En\&n=B5349463-1, archived information, accessed on-line, March 2014.

[3] Hazards in New Brunswick - Flood http://www.getprepared.gc.ca /cnt/hzd/flds-eng.aspx\#al, accessed on-line, March 2014.

[4] River Watch, http://geonb.snb.ca/riverwatch/index.html\#, accessed on-line, March 2014.

[5] Mioc, D., Nickerson, B., Anton, F., Fraser, D., McGillivray, E., Morton, A., Tang, P., Arp, J.P. \& Liang, G., Web-GIS application for flood prediction and monitoring, International Conference on Flood Recovery Innovation and Response, London, WIT Transactions on Ecology and the Environment (ISBN: 978-1-84564-132-0), WIT Press, 2008, pp. 145-154.

[6] Mioc, D., Anton, F., Nickerson, B., Santos, M., Adda, P., Tienaah, T., Ahmad, A., Mezouaghi, M., MacGillivray, E., Morton A. \& Tang, P., Flood Progression Modelling and Impact Analysis, Efficient Decision Support Systems - Practice and Challenges in Multidisciplinary Domains, Chiang Jao (Ed.), ISBN: 978-953-307-441-2, InTech, 2011, pp. 227-246. 